\title{
THE MATTER OF REVOLUTION
}





\section{THE}

MATTER

OF REVOLUTION

Science, Poetry, and Politics in the Age of Milton

\section{JOHN ROGERS}

Cornell University Press Ithaca and London 
Parts of Chapter 2 appeared in "The Great Work of Time: Marvell's Pastoral Historiography," reprinted from On the Celebrated and Neglected Poems of Andrew Marvell, edited by Claude J. Summers and Ted-Larry Pebworth, by permission of the University of Missouri Press. Copyright (C) 1992 by the Curators of the University of Missouri. An earlier version of Chapter 5 appeared as "Milton and the Mysterious Terms of History," ELH 57 (1990). Reprinted by permission of the Johns Hopkins University Press.

\section{Copyright $(\mathcal{C} 1996$ by Cornell University}

All rights reserved. Except for brief quotations in a review, this book, or parts thereof, must not be reproduced in any form without permission in writing from the publisher. For information, address Cornell University Press, Sage House, 512 East State Street, Ithaca, New York $1485^{\circ}$.

First published 1996 by Cornell University Press.

First printing, Cornell Paperbacks, 1998.

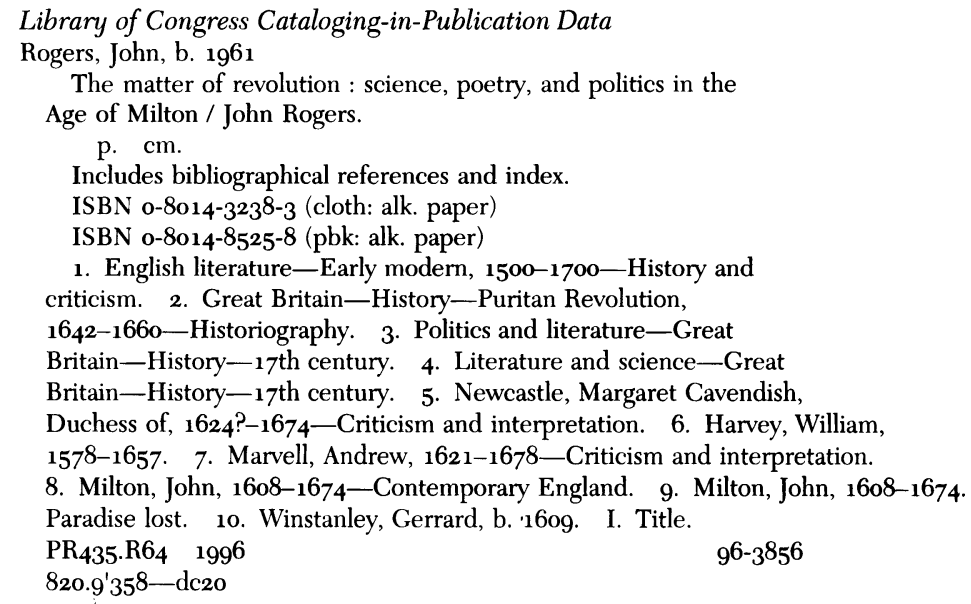

Cornell University Press strives to utilize environmentally responsible suppliers and materials to the fullest extent possible in the publishing of its books. Such materials include vegetable-based, low-VOC inks and acid-free papers that are also either recycled, totally chlorine-free, or partly composed of nonwood fibers.

$\begin{array}{llllllllllllll}\text { Cloth printing } & 10 & 9 & 8 & 7 & 6 & 5 & 4 & 3 & 2 & & \\ \text { Paperback printing } & & 10 & 9 & 8 & 7 & 6 & 5 & 4 & 3 & 2 & 1\end{array}$


In memory of Kipp Rogers 1957-1990 
